\title{
ECOLOGY AND ESCHATOLOGY: A NEGLECTED DIMENSION
}

\author{
by Francis Bridger
}

\section{Background}

At the conclusion of his 1989 Tyndale Ethics Lecture, Donald Hay posed the question: 'Are there significant contributions from the biblical themes of redemption and the Last Things that should inform our discussion of these (environmental) issues?' 1 In this article it is proposed to sketch some of the connections between ecology and eschatology which make it clear that Hay's question can unequivocally be answered in the affirmative.

The first thing to note is that until recently, theological ethicists have largely neglected the eschatological dimension in ecological discussion. Paul Santmire has consequently characterised the development of Christian ecological ethics in terms of two approaches based on differing 'motifs'. The first he designates 'the spiritual motif' by which he means that concern about earthly things is overtaken by concern about the spiritual or other-worldly. This, he argues, is the dominant idea to be found in John's gospel and in Hebrews. The central thought or metaphor is that of ascent and the Christian's vision is focused on the spiritual rather than the material world: "The Pauline vision of the Christian standing in solidarity with the whole creation at the very end is thereby eclipsed. ${ }^{2}$ It is this motif which, in Santmire's view, has dominated Christian history and which controls the thought of the majority of modern biblical scholars.

Over and against this Santmire sets what he calls 'an ecological reading of biblical faith' in which we see an ecological motif in Jesus' proclamation of the kingdom, in the apocalyptic theology of Paul and in the development of a

${ }^{1}$ 'Christians in the Global Greenhouse', Tyn B. 41.1 (1990) 126.

${ }^{2} \mathrm{H}$. Paul Santmire, The Traoail of Nature (Philadelphia, Fortress Press 1985) 217-18. 
cosmic Christology. The frame of reference for an ethic of the environment thus shifts from creation to new creation. Eschatology becomes the critical category.

If contemporary Christian theologians took that kind of approach to biblical faith seriously. . .that could lead to a new birth of Christian thought about nature. The travail of nature in Christian theology could come to a blessed ending. ${ }^{3}$

If Santmire is correct, we are justified in concluding that with a few recent exceptions ${ }^{4}$ (of whom Jurgen Moltmann is the most notable) the treatment of ecology has centred almost exclusively on refining and developing a stewardship ethic based on the concept of dominion found in the creation narratives and worked out in Old Testament social legislation. Hay's essay is an exemplary discussion of this kind.

We are faced, then, with two significantly different approaches. One would ground ecological ethics in the preservation of the created order commanded in the creation narratives and required by the role of vicegerent given to human beings through the bestowal of the imago dei. The other would accept this but interpret it from an eschatological perspective so that the original creation is seen as a prototype of the new creation. Ecological ethics on this account is rooted in the kingdom which is to come: it is anticipatory. It is this second interpretation with which we shall be concerned in this article.

\section{The Greening of Eschatology}

Although the link between eschatology and ecology can be argued from a number of angles, we shall concentrate upon two: (1) the significance of eschatological language; and (2) the vision of a consummated creation as it appears in Paul.

\footnotetext{
${ }^{3}$ Loc. cit.

${ }^{4}$ The upsurge in ecological interest in the 1980 s has generated an increasing volume of publications of which the following, in addition to works cited in this article, are representative: L. Wilkinson (ed), Earthkeeping: Christian Stewardship of Natural Resources (Philadelphia, Eerdmans 1980); W. Granberg-Michaelson, $A$ Worldly Spirituality (San Francisco, Harper \& Row 1984); D.J. Hall, Imaging God (Grand Rapids, Eerdmans 1986); Ian Bradley, God is Green (London, DLT 1990). Perhaps the most influential has been Moltmann's God in Creation (cited note 7 below) which is magisterial in its scope and depth.
} 


\section{II.1 Eschatological Language}

Our starting point must be to note, but not be controlled by, the distinction between eschatology and apocalyptic which has been the subject of considerable scholarly debate. ${ }^{5}$ For our purposes, apocalyptic can be defined as it is used in popular discourse: namely a way of speaking about future events which portend disaster. Eschatology, on the other hand, although future oriented need not major on doom: the present and the future can be seen as somehow related so that the qualitative difference between the 'now' and the 'not yet' is not absolute. Although these definitions fail to do justice to the complexities of the technical discussion, for the purpose of relating eschatological to ecological ethics they will suffice.

It is worth noticing at this point that contemporary western culture readily embraces apocalyptic thought as part of its everyday world-view. In the 1980 s this has taken the form of speculation about nuclear war; 6 however, this looks like being replaced in the 1990 s by fear of ecological disaster. ${ }^{7}$ Christopher Rowland writes:

\footnotetext{
${ }^{5}$ For a review of the debate, see P.D. Hanson, Interpreter's Dictionary of the Bible, Supplementary Volume (Nashville, Abingdon Press 1976) 29-30. Also, John E. Goldingay, Daniel, (Texas, Word Books 1989) 320. For fuller discussion, see Hanson, The Dawn of Apocalptic (Philadelphia, Fortress Press 1975) 10-12; Visionaries and Their Apocalypses (Philadelphia, Fortress 1983 1-15; John J. Collins, 'Apocalypse: The Morphology of a Genre', Semeia 14 1979; The Apocalyptic Imagination (New York, Crossroads 1984) Ch. 1; Christopher Rowland, The Open Heaven (London, SPCK 1982) Chs. 1-3 but esp. 70-72; D.S. Russell, Apocalyptic Ancient and Modern, Fortress (Philadelphia 1978).

${ }^{6}$ Cf. P.D. Hanson, Visionaries 8: 'Further abetting the renewed interest in apocalyptic is no doubt the precariousness of our times. Against the dark backdrop of the death clouds of Hiroshima and Nagasaki. . there arises the dread awareness that nuclear proliferation has run out of control, making, in the minds of many sober scientists, nuclear war a statistical probability before the year 2000.' See also, Alan Race (ed.), Theology Against the Nuclear Horizon (London, SCM 1988), section 2 'Continuing Apocalyptic'.

${ }^{7} \mathrm{Cf}$. Ian Bradley op. cit. 1: 'There can be little doubt that the threat posed by human exploitation and pollution of the natural environment is the most serious problem facing the world as we enter the last decade of the twentieth century. The scale of the ecological crisis is enormous and rising all the time. . : Compare Jurgen Moltmann, God in Creation (London, SCM 1985) xi: What we call the environmental crisis. . is a crisis of life on this planet, a crisis so comprehensive and so irreversible that it can not unjustly be described as apocalyptic'.
} 
Apocalyptic is a word which is widely used today, not only in theological debate but also in common parlance. Its secular use normally arises when social and economic events have taken such a disastrous turn that commentators look with foreboding on the future of society. ${ }^{8}$

The role of apocalyptic language, therefore, in our present context is to denote urgency, a sense of crisis, a need to do something in order to avert the End. In this respect, it functions as a catalyst for change: in sociology of knowledge terms it 'acts back' upon the present by holding out the prospect of a future which is intolerable or is no future at all.

John J. Collins has suggested that apocalyptic language thus fulfils a threefold purpose: ${ }^{9}$ firstly, it is expressive. It uses symbols and imagery 'to articulate a sense or feeling about the world'. It enables a society to articulate its attitude to contemporary problems. In this respect, apocalyptic language is part of a socially constructed interpretation of reality, part of which is an interpretation of the present which draws upon images of the future.

Secondly, it is commissive. Apocalyptic language 'commits us to a view of the world for the sake of the actions and attitudes that are entailed'. In other words, it exerts ethical pressure and demands ethical decision followed by action on a social scale. This last phrase is important because a frequent characteristic of apocalyptic is that it engenders political action precisely for the reason that only such action is perceived as being able to ward off the future doom to which apocalyptic images point.

Thirdly, it is denunciatory in that it gives rise to 'a powerful rhetoric for denouncing the deficiencies of this world'. Such rhetoric may issue in action or, alternatively, may do no more than enable a society or group to come to terms with the inevitable. Both are possible functions of this kind of language. In each case, however, apocalyptic represents 'a symbolic world where the integrity of values can be maintained in the face of social and political powerlessness and even the threat of death'.

${ }^{8}$ Rowland op. cit. 23.

${ }^{9}$ The Apocalyptic Imagination 215. 
All these aspects can be found in modern ecological writing both secular and religious. We have only to think of the lurid forecasts of the effects of ozone depletion upon world climate and the Ottowa 1990 international agreement on the phasing out of CFCs to appreciate that apocalyptic language is already acting back upon the present. None of these characteristics is, of course, distinctively Christian. They amount to a phenomenological description in which the meaning and content of the imagery are bracketed out. When we turn to Christian apocalyptic thought, however, (especially that of the apostle Paul), we see resonances with the above but with some significant filling out. It is this which distinguishes biblical from modern secular apocalyptic. ${ }^{10}$

At this point, apocalyptic and eschatological language begin to shade into each other. The doctrine of the last things becomes focused on the ultimate End and this act of focusing produces ethical re-evaluation in the here and now. ${ }^{11}$ Yet it would be a mistake to see the function of apocalyptic eschatology only in terms of the dynamic relationship between fear for the future and action in the present. The other side of the eschatological coin is less concerned with doom and more concerned with continuity. It is to this we now turn.

The rise of a Christian ecological ethic based on eschatology must be set within an understanding of the overall relationship between eschatology and ethics. According to Helmut Thielicke, Theological ethics is eschatological or it is nothing ${ }^{\prime 2}$ a contention which has been taken up in detail by, inter alia, Pannenberg and Moltmann. At the heart of this claim lies the belief that the 'eschatological future reveals itself in Jesus as the highest good for which men can strive, as the fulfilling destiny of human life and the goal of the whole

\footnotetext{
${ }^{10}$ For an interesting analysis of this difference see Frederick A Kreuziger, Apocalypse and Science Fiction: A Dialectic of Religious and Secular Soteriologies (Chico, Scholars Press 1982).

${ }^{11}$ Thus B. Chilton and J.I. McDonald in Jesus and the Ethics of the Kingdom (London, SPCK 1987) 129 "The performance of the Kingdom is the enactment or expression of the Kingdom within the context of the conditioned and historical. It therefore brings ethics and eschatology into mutual interaction.' Cf. also Carl E. Braaten, Eschatology and Ethics (Minnesota, Augsburg Publishing House 1974) Ch. 7.

${ }^{12}$ Theological Ethics (Philadelphia, Fortress 1966) I, 47.
} 
creation' ${ }^{13}$ But it is important not to confuse this simply with imitation ethics or moralistic exhortation. In Jesus we have a glimpse of the kingdom of God which is wrought by the inbreaking of the future into the present in Christ. As such it is an act entirely of God's power of which the Resurrection of Jesus is the first fruit. 'Christian ethics, in other words, is oriented toward revelation and not toward morality. ${ }^{14}$

This should make us wary of making the connection between eschatology and ethics in terms of autonomous human political activity. We cannot bring in the kingdom of Godonly God Himself can achieve that. Thus we are left with the question of how eschatological ethics acts back upon the present, particularly in relation to the environment?

This question can be answered in three ways. In the first place, we need to remember that we and the world lie between the two decisive acts of God in the affairs of the world, namely 'His past act in Jesus Christ and His future act when the final theophany will usher in the resurrection of the dead and the last judgment' ${ }^{15}$ This means that our ethics looks both back and forward. Yet even the looking back is not to some kind of law code but to the decisive intervention of God in His Son who in His person represents the inauguration of the future kingdom. Thus the material reality of the eschatological kingdom of God. . .has been revealed through its proleptic presence in Jesus of Nazareth'. ${ }^{16}$

This leads, secondly, to a point which directly addresses the status of the created order and thereby the question of ecology. The coming of the kingdom does not overthrow the natural order but rather vindicates it. As Oliver O'Donovan has noted, 'In the resurrection of Christ, creation is restored and the kingdom of God dawns' ${ }^{17}$ The implication of this is that, as we shall see in the next section, Pauline references to the creation groaning in travail (Romans 8) and the reconciliation of all things to God through the Cross

\footnotetext{
${ }^{13}$ Braaten op. cit 114.

${ }^{14}$ Loc. cit.

15J. Christiaan Becker, Paul's Apocalyptic Gospel: The Coming Triumph of God (Philadelphia, Fortress 1982) 87.

16 Braaten op. cit. 111.

${ }^{17}$ O.M.T. O'Donovan, Resurrection and Moral Order (Leicester, IVP, 1988$) 15$.
} 
(Coloss. 1) embrace the whole of creation, not simply the human part of it.

Thirdly, the eschatological vision exerts ethical pressure now precisely because it holds forth a picture of a future reality which has already begun. It would therefore be inconsistent for believers to continue acting as if this had no present relevance. In the words of J. Christaan Becker:

The ethical activity of the Christian is motivated not only of Christ in the Spirit but also by the beckoning power of God's kingdom. And so God's past act in Christ and His future act in the resurrection of the dead converge on Christian life in the present. ${ }^{18}$

The life of ethical obedience, however, cannot be regarded as dualistic. The Incarnation and Resurrection prove that the whole of God's creation is to be vindicated. This forces us not to withdraw from the world but to take its fate seriously. More positively, we can say that

Paul's apocalyptic faith in the transformation of the creation at the time of God's coming reign compels an ethic that strains and labours to move God's creation toward that future triumph of God promised in Jesus Christ and to which the presence of the Spirit propels us. ${ }^{19}$

Becker's image of the beckoning eschaton is a powerful one for it presents a future which at one and the same time stands before us but not simpliciter. It is an image which respects the freedom and integrity of persons: we are beckoned, invited, drawn-not summoned, forced or dragooned. Human agency is respected. Yet the other side of this is an ethical seriousness which derives from the truth that the God who beckons is also the God who judges:

...the apocalyptic hour will demand from us a final accountability of our stewardship over God's creation and of our active participation in establishing signs and beach-heads of the kingdom in our world. ${ }^{20}$

The result is that the consummation, seen as both triumph and judgment, requires from us an ethic that must embrace the values and goals of the kingdom now 'because it is existentially impossible to believe in God's coming triumph and

\footnotetext{
${ }^{18}$ Becker loc. cit.

${ }^{19}$ Ibid. 111.

${ }^{20}$ Ibid. 110.
} 
to claim His Holy Spirit without a lifestyle that conforms to that faith'. ${ }^{21}$ This is as true of ecology as of sexuality (significantly another focus of the relationship between ethics and eschatology in Paul) or any other ethical problem.

\section{II.2 Eschatology and Ecology in Paul}

But what kind of consummation does Paul have in mind? Does it include material as well as spiritual reality? Is there an inner connection within Paul's theology between creation and consummation which would lead us to take the created order more seriously?

We need to remember that for Paul, as for other New Testament writers drawing upon their Jewish roots, there is a positive correlation between creation and salvation. ${ }^{22}$ The structure of Paul's thought is governed by the belief that creation and consummation are tied together. Four aspects make this clear.

(a) analogy: for Paul, the new heaven and the new earth are not discontinuous with the old but are continuous. The acts of God at the beginning and end of the world are to conform to one another. The connecting link can be found in Christ for all things were made in Him, by Him and for Him (Col.1: 16-17). $\mathrm{He}$ is both the Creator and Consummator.

(b) contrast: as a form of analogy, contrast works by drawing attention to dissimilarities. Thus, although the new creation is related to the old, it will nevertheless be better since it will be freed from the corruption of sin. This is the point of the AdamChrist contrast in Romans 5 where the curse of Genesis 3:17-18 resulting from Adam's disobedience is lifted by the obedience of the second Adam. The fact that it is a curse upon the earth which Christ lifts is itself ecologically significant.

(c) restoration-transformation: the new creation will not amount to a return to Eden but will be a renewing transformation of all that has gone before. This idea was already contained in Messianic Judaism and it can be found in such passages as Isaiah 30: 26 where the light of the heavenly bodies in the new

\footnotetext{
${ }^{21}$ Loc. cit.

${ }^{22}$ For what follows, see N.A. Dahl, 'Christ, Creation and the Church', in W.D. Davies and D. Daube (eds), The Background of the New Testament and Its Eschatology (CUP 1964) 422-443.
} 
creation will exceed that of the old (cf Rev. 21:23 where God and Christ will themselves constitute the new light). For Paul, however, it is the Resurrection to incorruptibility which supremely expresses the eschatological transformation. In 1 Cor 15, the continuities and discontinuities between old and new are set forth such that the reader can be left in no doubt that the Resurrection of Christ heralds not only humanity's future resurrection but the vindication of the whole created order.

(d) pre-existence and predestination: a significant aspect of Paul's thought is the way in which he portrays present and future states of affairs as having already existed in the mind and will of God before even coming into being. In Ephes. 1:3-4 he speaks of God having chosen and blessed us in Christ before the creation of the world'. A few verses later, he links this with the mystery of redemption which will be made known or put into effect 'when the times have reached their fulfilment' $(1: 9-10)$. The result is that for Paul, as for his contemporaries, the end will bring the final realisation of what from the beginning was the will of God the Creator who is Himself the first and the last' ${ }^{23}$

The common idea behind all these aspects is that creation and new creation are brought together in Christ. He is the unifying principle who gives both coherence and continuity. Moreover, it is crucial to note that in Paul's theology, God did not step in to remedy the breakdown of the original creation as a kind of contingency action but that both creation and consummation existed in the mind of God from the beginning:

The fundamental idea here is not the conformity of the eschatological salvation with the original creation but that creation as described in Genesis prefigures the whole history of the world, including its eschatological fulfilment. ${ }^{24}$

Two passages which embody this line of theological reasoning are Romans 8:18-30 and Colossians 1:15-20. Both of these can be read as ecological statements. Although space does not permit detailed exegesis, a brief consideration will indicate their

${ }^{23}$ Ibid. 429.

${ }^{24}$ Loc. cit. 
relevance. In Romans 8, the central metaphor Paul employs is that of pregnancy, labour and childbirth:

We know that the whole creation has been groaning as in the pains of childbirth right up to the present time (v. 22).

The metaphor was common in contemporary apocalyptic and rabbinic Judaism as well as in Greek thought ${ }^{25}$ so that, in Dunn's words, 'it was a natural one to seize on for description of a period of turmoil and anguish likely to end in a new order of things' ${ }^{26}$ What is unique to Paul, however, is the series of twists he gives to the metaphor. The first of these can be found in the way in which he relativises suffering in verse 18: 'I consider that our present sufferings are not worth comparing with the glory that will be revealed. . .' This is clearly designed to enable believers to set their personal pain in a longer perspective. But he then goes on to argue that not only are Christians living in hope but so also is the entire created order. The present is only the prelude to universal redemption: the creation itself will be liberated from its bondage to decay and brought into the glorious freedom of the children of God' (v. 21). Hence Kasemann comments that,

By allowing Christians to suffer with Christ, the Spirit brings about the transforming of the old creation into an expectancy of glorification and an initial participation in this. Hope, then, reaches beyond believers to creation as a whole. 27

The precise meaning of the term creation in this verse has been hotly disputed. A consensus now exists, however, following Kasemann that Paul is referring to non-human creation and that he is alluding therefore to the re-creation of the world which elsewhere is identified with the parousia. If this is the case, Romans 8 is pivotal for the development of an ecological

${ }^{25}$ Cf. C.E.B. Cranfield, The Epistle to the Romans (Edinburgh, T \& T Clark 1975) I, 416; J. Ziesler, Paul's Letter to the Romans (London, SCM/Philadelphia, Trinity Press 1989) 218; Dale Allison, The End of the Ages Has Come (Philadelphia, Fortress 1987) Ch. 2; D.S. Russell in Apocalyptic Ancient and Modern (London, SCM 1978) 9, notes that the metaphor is found in Qumran apocalyptic also. cf. G. Vermes, The Dead Sea Scrolls in English (Harmondsworth, Penguin 1975, 2nd edn) 157. For a contrary view see E.P. Sanders, Jesus and Judaism (London, SCM 1985) 124, 130.

${ }^{26}$ J.D.G. Dunn, Commentary on Romans 1-8 (Waco, Word Books 1988) 472.

${ }^{27}$ Cf. E. Kasemann, Commentary on Romans (London, SCM 1980) 234. 
ethic since 'redemption embraces the material creation. . as the climax to a divine purpose, pursued from the beginning of creation, now nearing its fulfilment'. ${ }^{28}$

When we turn to Colossians, we discover a different slant in which the high Christology of the first chapter acts as the centrepiece for a theological interpretation of the origin and ultimate purpose of creation. ${ }^{29}$ Paul's assertion in 1:15 establishes the connection with Genesis: Christ is both the image of God (cf. Gen. 1:27) and the firstborn of all creation. In describing Him thus, Paul is not putting forward the Son as a created being (in the light of what follows this would be inconceivable) but rather as the prior principle and agent of creation. As Lawrence Osborn observes, 'it is a characteristically Jewish expression of pre-existence' ${ }^{30}$ Verses 16 and 17 expand the point by making clear that creation owes its existence, continuance and goal to Christ: ' $\mathrm{He}$ is the sole basis of unity and purpose in the cosmos' ${ }^{31}$

In consequence, we find in these two passages a profound affirmation of the material order which is Christologically underwritten in the Incarnation and Resurrection. Moreover, this affirmation is cast in terms of an inner connection between the past, present and future. The Christological axis on which Paul's theology turns looks both back and forward.

What this does to the present and to the interim between the Resurrection and the parousia is to shape in turn an ethic which prefigures the coming eschatological rule of Christ. The logic of creation and salvation expressed in the concept of prefiguring thus extends to ethics. In the Christological link between soteriology and eschatology, therefore, we begin to find a basis for ecological ethics arising out of God's vindication of creation in the new creation. The future, as we have previously noted, acts back upon the present.

\footnotetext{
${ }^{28}$ Dunn op. cit. 474.

${ }^{29}$ Cf. Peter T. O'Brien, Commentary on Colossians, Philemon (Waco, Word Books 1982) 31-57. Also, N.T. Wright, Colossians and Philemon (Leicester, IVP/Grand Rapids, Eerdmans 1986) 70: 'The true humanity of Jesus is the climax of the history of creation and at the same time the starting point of the new creation'.

${ }^{30}$ Lawrence Osborne, Stewards of Creation: Environmentalism in the Light of Biblical Teaching (Oxford, Latimer House 1990) 36.

${ }^{31}$ Ibid. 37.
} 


\section{Conclusion}

The primary argument for ecological responsibility lies in the connection between old and new creation outlined in the previous section. We are called to be stewards of the earth by virtue not simply of our orientation to the Edenic command of the Creator but also because of our orientation to the future. In acting to preserve and enhance the created order we are pointing to the coming rule of God in Christ.

What we do ecologically, therefore, acts as a sign:

the preservation of creation is no longer an action that has a significance of its own. . .it is rather itself an action pointing towards a goal which has its direction, its meaning and its value in its indication of the hope for the world which God will realise. ${ }^{32}$

Ecological ethics are not, therefore, anthropocentric: they testify to the vindicating acts of God in creation and redemption. Moreover, they are the ethics of faith:

What faith can do, by the power of God in Christ, to preserve the world of creation is to perform untiringly token acts as signs, manifestations of the future salvation in the sphere of the natural world, which testify that God has opened His new world for all created things. ${ }^{33}$

Paradoxically, the fact that it is God who will bring about a new order of creation at the End and that we are merely erecting signposts to that future need not act as a disincentive. Rather it frees us from the burden of ethical and technological autonomy and makes it clear that human claims to sovereignty are relative. The knowledge that it is God's world, that our efforts are not directed toward the construction of an ideal utopia but that we are, under God, building bridgeheads of the kingdom serves to humble us and to bring us to the place of ethical obedience. In the connection between eschatology and ethics we thereby find a key for understanding Christian ethics as a whole.

32Odil Steck, World and Environment (Nashville, Abingdon Press 1978) 292.

${ }^{33}$ Ibid. 293. 